\title{
Vertical Housing Development, on Control Regional Bali Regulation of Building Height
}

\author{
Ni Luh Putu Dessy Dharmayanty ${ }^{1}$, Syamsul Alam Paturusi ${ }^{2}$, Ngakan Ketut Acwin Dwijendra ${ }^{3}$,
} Ni Ketut Agusinta Dewi ${ }^{4}$

\author{
${ }^{1}$ Doctoral Program in Engineering Sciences Faculty of Engineering, Udayana University Denpasar, Bali, Indonesia \\ putudessydharmayanty@gmail.com \\ ${ }^{2}$ Doctoral Program in Engineering Sciences Faculty of Engineering, Udayana University Denpasar, Bali, Indonesia \\ syamsul_alam_paturusi@yahoo.fr \\ ${ }^{3}$ Doctoral Program in Engineering Sciences Faculty of Engineering, Udayana University Denpasar, Bali, Indonesia \\ acwin@unud.ac.id \\ ${ }^{4}$ Doctoral Program in Engineering Sciences Faculty of Engineering, Udayana University Denpasar, Bali, Indonesia \\ nkadewi@gmail.com
}

\begin{abstract}
Regional Regulation of the Province of Bali concerning the height of buildings has been known since 1974 until now. The development of tourism has an impact on the high price of land in Bali especially in urban areas and tourist accommodation. The increase in the number of urban residents and the high number of shortages of decent housing, opens a discourse on Vertical Housing development, through the National program that has been started since 2011. The development of Vertical Housing in Bali has not been responded to optimally by both the Regional Government and the Community. However, the need for housing and various other factors are increasing and unresolved with existing programs, therefore or unwillingly or dislike of the people of Bali must prepare themselves to be able to receive Vertical Housing development in the Urban area. Then how is this Regulatory Control related to the program? Then how far is the effect? Through this research, this will be traced qualitatively.
\end{abstract}

Keywords — Proper Residential Needs, Regional Regulations, Vertical Housing.

\section{INTRODUCTION}

$\mathrm{P}$ rovincial Governments with Regional Regulations on Spatial Planning, Building Management and Environment have been owned since 1974 (regional regulations 2.3 and 4). Specifically about building a building is Regional Regulation number 4 of 1974, which in one article stipulates that the height of buildings in the area of Bali Province is limited to the height of a Coconut Tree. And fulfill the rules of the values of Balinese Architecture. In its implementation, the community and the institution holding the authority for licensing difficulties determine how to measure it. This is because the height of coconut trees is very varied and not all functions of modern buildings can be adapted to traditional Balinese architecture.

On this matter, the Regional Government of Bali Province revises the Regional Regulation by revising and further explaining the implementation of the regulation through Bali Provincial Regulation number 5 of 2005, concerning Balinese Architecture. In this regulation it is explained how to translate and measure the height of a building as high as the coconut tree. Then the term can be translated as high as a coconut tree as 15 meters from the ground, to the limit of the roof corner meeting.

When Since the promulgation of the Regional Regulation of Bali Province, all Regional Regulations relating to building such as RTRWP, RTRWK even to the planned RDTRK or RTBL, also mandate.

In line with the development of tourism in Bali, the need for accommodation also increased, urbanization and migration of the population was inevitable. The need for housing has also increased. In 2015, the number of backlogs in Bali increased, reaching 27,000 units in Bali Province and 7500 units in Badung Regency and 8500 in Denpasar City. This triggers an increase in added value of land in urban areas and accommodation, so that the impact should be taken into account by investors and the public.

Vertical Housing, is one of the solutions to overcome the problem of housing shortages for urban communities, but 
until now the government and the community have not responded well. Then what is the relationship between building height regulation and the development of Vertical Housing? Why? And what are the alternatives / solutions to overcome them? In this study, the extent to which the control of the Perda will play a role.

In this study, we will take a sample of the height of buildings in the Badung Regency region, considering that Badung Regency ranks highest at $20.31 \%$ of vertical housing development and Vertical accommodation.

By using qualitative research methods, observation techniques, interviews and experience as implementing regulations, what control will occur.

\section{LITERATUR RIVIEW}

\section{A. Principles of Architecture (Balance) as The Basis for Regulation in Designing Buildings}

Minister of Public Works Regulation number 29/PRT/ M/2006 concerning Guidelines for Technical Requirements for Building Buildings article 4 (four) and attachments in part II, specifically II.2.8 concerning building heights determined for high-rise buildings, medium-rise buildings, low-rise buildings and the calculation is based on Urban Development Considerations, Developmental Intensity Policy, Land / Environment Supporting Power, and Environmental Balance and Harmony.

The balance calculation is one of the Basic Principles of Architectural Design to be used as a guide in planning an architectural work. There are 7 (seven) basic principles, including: Proportion, Cadence, Composition, Balance (Balance), Point of Interest, Scale (Scale) and Unity (Unity).

In calculating one of these principles, namely (balance), the government applies the Building Floor Coefficient (KLB) and Building Base Coefficient (KDB) which in each region in urban areas are different. Building Floor Coefficient (KLB) is a "percentage number comparison between the total number of Building Floors to be built with the available Land Area". Whereas the Building Base Coefficient (KDB) is "the percentage of the floor area of a building that covers the ground versus the area of the land where the building is located". KLB and KDB aim to bring the balance of space between the Open Space and the Built Room. Thus it will provide comfort to residents and the surrounding environment.

How to calculate and the amount of percentage of outbreaks and $\mathrm{KDB}$ in an area varies according to the respective Regional Regulations, but in principle it can meet the principle of balance. The way to calculate the two coefficients is as follows. If we have a land area of $1000 \mathrm{~m} 2$, with the provisions of $\mathrm{KDB}$ amounting to $60 \%$, then the area of land that can be constructed is $600 \mathrm{~m} 2$. With the same land area, if the provisions of $\mathrm{KLB}=2.4 \%$, then the total building area that can be built is $2400 \mathrm{~m} 2(2.4 \mathrm{x} 1000)$.

From the above, a balance between open space and builtup space will be achieved. The Regional Government of Bali reacts to it by rearranging it in the Regional Regulations concerning Building Arrangements, including the Height of the Building that is permitted to be built.

In the Badung RTRWK article 62, regarding the general provisions of the City System Zoning regulations, it has been stated that the structure of the building is directed to medium to high intensity, both horizontally and vertically at a maximum of 15 meters, and the city's green open space by $30 \%$.

Badung District Regulation number 3 in 2016, concerning Building Buildings, Article 23 paragraph 2 and 3 states that the height of the building is vertical (up to 15 meters high, except for special function buildings) and has a lower level / basement of 7 meters.

The following figure is an example of the application of building height regulations in tall buildings in Bali.

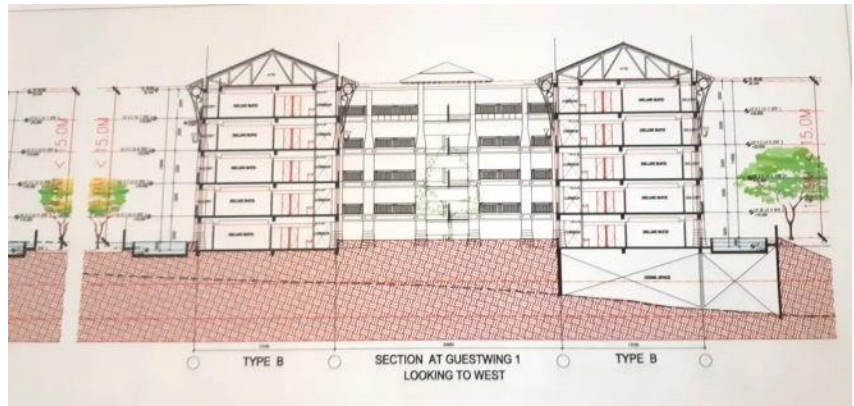

Fig. 1. Example of measuring the height of a building.

\section{B. Factors Influencing Housing Development}

The existence of a housing can affect the development of a region, and conversely development activities in a region can affect the development of housing. According to Siswono (Blog spot January 21, 2013) several aspects that affect housing development include:

a) Geographic factors, in this case the location of housing that is remote and difficult to reach will be very long development.

b) Population Factors, the development of the population will be a development resource and requires housing.

c) Institutional factors, are government regulations from the center to the regions regarding housing control.

d) Swadaya Factors and Community Participation, for selfhelp factor housing is rather difficult to do, but the role of the community, especially the private community, can play a role as a housing provider.

e) Economic Factors and Affordability of Purchasing Power, related to livelihoods and economic development of a high area, this can improve housing development. The higher the income, the greater the chance to own a house.

f) Factors of facilities and infrastructure, complete facilities and infrastructure in housing and the environment.

g) Land Factors, increases in land prices also affect housing developments.

h) Factors in Science and Technology, with the creation 
and development of new technologies in the field of construction services and building materials, the process of building is getting easier and faster.

According to Amos Rapoport (1969) in his book House, form and cultural added influential factors besides the above factors, including:

1) Culture / culture factors affect housing development, meaning that the shape of the house is influenced by the availability of local materials and the way of life of residents and their climate and environment.

2) Religious factors or beliefs, these factors are often more dominant than other factors, because people believe that housing is a form of nature (Microcosmos) of the whole form of the universe (Macrocosnos).

3) Behavior Factors, influence each other's forms and patterns of space and housing, especially regarding the concepts of private, semi-private and public spaces.

From the existence of these factors, the correlation of regulatory factors is one of the factors that influence the development of Vertical Housing in the City.

\section{RESEARCHMETHODS}

In this research qualitative research methods are used with observation and interviews with respondents who are considered to know and experience in implementing regulations regarding building heights in Bali. The selection of respondents is based on the profession and assignment concerned and is considered to be the most knowledgeable or experienced in the process of implementing the Local Regulation being examined.

\section{RESULT ANDDISCUSSION}

\section{A. Figures and Tables Effects of Building Height Regulations on Vertical Housing}

The highest housing growth in each region is always in urban areas, so it is not surprising because of this, the need for shelter for urban residents continues to increase. Denpasar City and the Badung Regency Region each need 11000 units and 8000 units. Then why until now there has been no role from the private sector / community in the procurement of Vertical Housing.

Based on data and results of interviews with administrators and actors from the Real Estate Indonesia Branch of the Province of Bali, the factors that influence the development of Vertical Housing in Bali are basically the same as the development in other regions in Indonesia, but the problem has not yet been realized.

In their opinion that there are specific factors that make it rather difficult to develop Vertical Housing in Bali, namely the influence of traditional cultural factors and traditions based on Balinese Hindu beliefs, as well as Regulatory Factors on Building Height that can only be built 15 meters above and 7 meters down from the ground. In addition, it also deals with Building Base Coefficients and Building Floor
Coefficients which are constructive corridors that are binding in their physical manifestations.

With this regulation, coupled with the need for houses in urban areas that meet the criteria of location and other complementary infrastructure, making obstacles for the procurement of Vertical Housing.

\section{B. Building Height with Land}

Building height regulation affects the volume of space and the need for sufficient land area to find a flexible investment value and is able to provide added value and good environmental subsidies. The price of land in Denpasar City ranges from 500 million - 1.2 billion and 600 million - 1.5 billion in Badung Regency, with KDB in a $60 \%$ residential area which means that to build 100 residential units requires a land area of $3600 \mathrm{~m} 2$. With the calculation as follows:

$100 \times 36 \mathrm{~m} 2=3600 \mathrm{~m} 2$

Circulation $40 \%=1440 \mathrm{~m} 2$

Total building area $=5040 \mathrm{~m} 2$

With KDB $60 \%$, the required land area is $8400 \mathrm{~m} 2$ and $20 \%$ for environmental infrastructure $672 \mathrm{~m} 2$ so the land area needed is equal to $9072 \mathrm{~m} 2$. With the land area, if each floor requires an area of 5040 for 100 units with a floor height of 2.80 meters then the size of the building up to a maximum of 5 (five) layers and down to a maximum of 2 (two) layers, the total being 7 (seven) layers. that means there will be 700 housing units with type 36 .

Then if the average land price in urban areas is 800 million / acre, then a fee of Rp.72,800,000,000 is needed, with a standard building cost of Rp.5,000,000/ $\mathrm{m} 2 \times 25,200 \mathrm{~m} 2=$ Rp.126,000,000,000. The total for land and buildings is Rp.192,800,000,000 plus $30 \%$ for environmental arrangements and supporting facilities of Rp. $57,840,000,000$. So the total infestation is Rp.250,640,000,000.

Of the total investment if divided by 600 (one floor is assumed to be for supporting facilities) then the value of each unit ranges from Rp. 417 million - 500 million basic price / unit.

This simulation can be cheaper and can be more expensive depending on the financing scheme and method of payment from consumers.

In conclusion, with high land prices and limited size of permitted buildings the impact on the selling value of property units in Vertical Housing is relatively higher and the value of the investment is only a building.

This will be different if Vertical Housing is built in other areas where there are no regulations regarding building height restrictions. So that more than 10 (ten) layers can be built and more than 2 (two) layers down, the value of the infestation will quickly return to the cheaper unit price. 


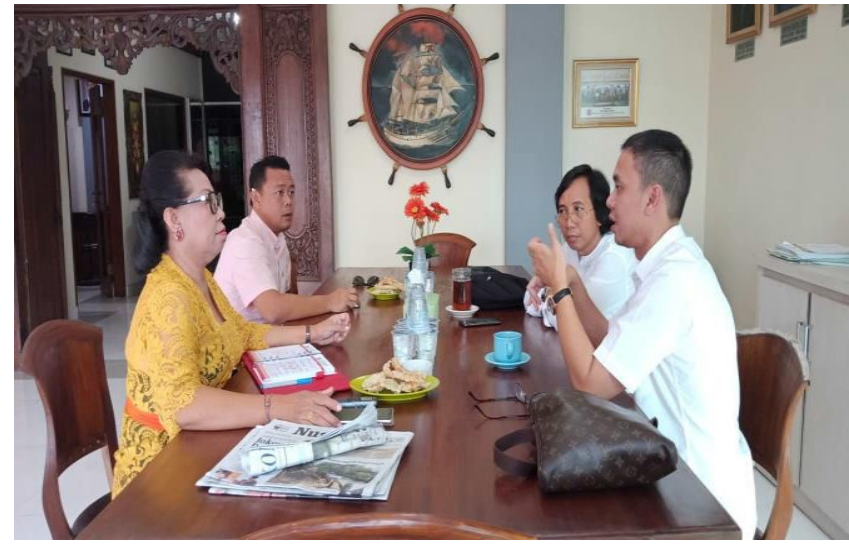

Fig. 2. Interview with REI Bali.

\section{The Effect of Building Height on Physical and Vertical Housing Building Facilities}

With the above conditions, the physical facilities of the building are doubted when compared to similar buildings in other regions, including:

\section{1) Roof Cover}

If the height of the building is 15 meters it is still possible to display the pyramid roof, but in fact in the field the roof design is often made by forgetting how to routinely maintain the shape of the roof. Every repair must use a lot of scaffolding equipment so that maintenance costs are high. Fact Second, if the building is close to the beach, the height of the 15-meter building creates a problem that the roof will receive a higher wind load (statements from the constructors of hotel buildings). Then for the third fact is about the space under the roof that is not functioning optimally, so that the funding funds are higher.

2) Vertical Transportation Facility

Vertical transportation facilities can be in the form of stairs, escalators and elevators. For residential homes, the use of escalators is not recommended because it is considered less ergonomic. While the stairs are also less ergonomic if used more than three layers, unless it functions as an emergency ladder. So, the most appropriate choice is the elevator (elevator) because it is considered the most representative and ergonomic, it's just that the price is quite expensive. For one elevator unit the price ranges from 3-5 billion / unit, according to the capacity and type of product chosen. With the high price of elevator investment that is only used to accommodate five-story buildings is a function that is very "responsibility", because for the investment value of one minimal elevator used in buildings that have eight floors or more to achieve economic value.

Thus the existence of regulations regarding the height of the building has led to efficient utilization of vertical transportation facilities, so that unit prices in Bali become more expensive and maintenance costs become higher.

This has an effect on the decision to use the stairs, which ultimately only used in official housing with residents who are on average 28-45 years old, if they are above they will choose to stay on the first or second floor only.

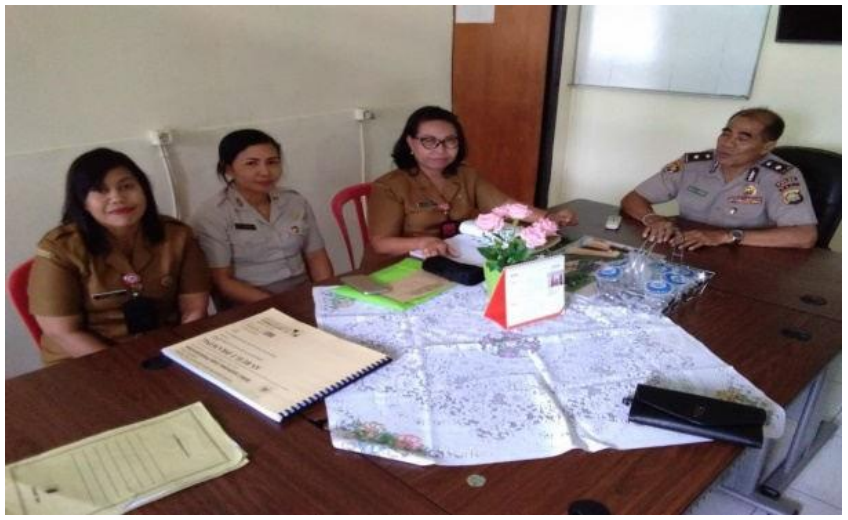

Fig. 3. Interview with Bali Police Housing Manager.

Based on the data obtained, the affirmation of regional regulations in Bali is slightly different from government regulations throughout Indonesia, although it is not contradictory but has an impact on the economic value of vertical housing.

\section{CONCLUSION}

PFrom the discussion above, it can be concluded that the Regional Regulations of Provincial and District Governments in Bali concerning the Building Height in the present (the era above 2000) turned out to affect economic factors in the procurement of housing.

Economic factors here are also influenced by the increase in land prices and in-efficiency of the use of high-rise building facilities, because the height of the permitted buildings is classified as "responsibility" and not yet classified as a Highrisk Building.

Both of these things cause high costs for procurement and maintenance, so that property entrepreneurs become reluctant to enter the area. Because even if it is not forced to solve the problem, the location to be searched is at a lower land price, but does not meet the ideal Vertical Housing criteria.

For this reason, it is necessary to review the regulation, if it is necessary to conduct an evaluation, especially in the urban housing zone which is not an area of Balinese cultural heritage.

\section{REFERENCES}

[1] Blogspot.co.id. Study of Housing and Settlement Theory (study and learning, 01-21-2003).

[2] Barbara Ward, Human Satisfaction crisis and apportinity, University of Indonesia Faculty of Technology Library

[3] Creswell, W John. 1977. Qualitative Inquiry and Research Design (coosing among five approaches second edition)

[4] Dwijendra Acwin Ngakan Ketut. 2014. Inproving Quality and acceptability in affordable Housing Provision Project in Bali

[5] Gde Line Set by IGN, at all. 1981. Balinese Traditional Architecture.

[6] Peters Hendrik Jan; Wardana Wisnu. 2014. Discovering the Spirit of Bali (Costumary Village as Icon of Tri Hita Karana).

[7] Government Regulation number 14 of 2016, concerning the Implementation of Housing and Settlement Areas.

[8] Bali Provincial Government, 2015, Update on Housing Database and Settlement Area in Bali Province 
International Journal of Engineering and Emerging Technology Vol. 4 No. 2 July - December 2019

[9] Regional Regulation of the Province of Bali number 13 of 2009 concerning the Spatial Planning of the Province of Bali.

[10] Regional Regulation of Badung Regency number 26 of 2013, concerning the Badung Regency Spatial Plan.

[11] Regional Regulation of Badung Regency number 3 of 2016 concerning Building Buildings.

[12] Rapoport, Amos. 1969. House Form and Culture. Engelwood Cliffs, New York. Prentice Hall Inc.

[13] Rapoport, Amos. 1977. Human Aspect of Urban Form. Oxford Pergamon Press.

[14] Sadana, S. Agus. 2014. Settlement Area Planning. and Settlement Area.

[15] Setiawan, Haryadi. B. 2010. Architecture, Environment and Behavior, introduction to methodologies and applications. Gajah Mada University Press.

[16] Siregar, Laksmi G. 2005 Phenomenology in Architecture. University of Indonesia Press.

[17] Syamsul Alam Paturusi, 2016, Segregation of social space between Migrants and Indigenous Peoples, in Urban Settlements in Denpasar, Journal of Bali Studies, Volume 06, number 02, October 2016.

[18] Republic of Indonesia Law Number 1 of 2011 concerning Housing and Settlement Areas.

[19] Law of the Republic of Indonesia number 20 of 2011 concerning Flats. 